University of Nebraska - Lincoln

DigitalCommons@University of Nebraska - Lincoln

Publications, Agencies and Staff of the U.S.

Department of Commerce

U.S. Department of Commerce

2005

Ringed and bearded seal densities in the eastern Chukchi Sea, 1999-2000

John L. Bengtson

National Marine Mammal Laboratory, Alaska Fisheries Science Center, NOAA Fisheries NOAA

Lisa M. Hiruki-Raring

National Marine Mammal Laboratory, Alaska Fisheries Science Center, NOAA Fisheries NOAA

Michael A. Simpkins

National Marine Mammal Laboratory, Alaska Fisheries Science Center, NOAA Fisheries NOAA

Peter L. Boveng

National Marine Mammal Laboratory, Alaska Fisheries Science Center, NOAA Fisheries NOAA

Follow this and additional works at: https://digitalcommons.unl.edu/usdeptcommercepub

Part of the Environmental Sciences Commons

Bengtson, John L.; Hiruki-Raring, Lisa M.; Simpkins, Michael A.; and Boveng, Peter L., "Ringed and bearded seal densities in the eastern Chukchi Sea, 1999-2000" (2005). Publications, Agencies and Staff of the U.S. Department of Commerce. 143.

https://digitalcommons.unl.edu/usdeptcommercepub/143

This Article is brought to you for free and open access by the U.S. Department of Commerce at DigitalCommons@University of Nebraska - Lincoln. It has been accepted for inclusion in Publications, Agencies and Staff of the U.S. Department of Commerce by an authorized administrator of DigitalCommons@University of Nebraska - Lincoln. 


\section{Ringed and bearded seal densities in the eastern Chukchi Sea, 1999-2000}

Received: 3 May 2004/ Revised: 11 April 2005/ Accepted: 19 April 2005 / Published online: 26 July 2005

(C) Springer-Verlag 2005

\begin{abstract}
Aerial surveys were conducted in 1999 and 2000 to estimate the densities of ringed (Phoca hispida) and bearded (Erignathus barbatus) seals in the eastern Chukchi Sea. Survey lines were focused mainly on the coastal zone within $37 \mathrm{~km}$ of the shoreline, with additional lines flown $148-185 \mathrm{~km}$ offshore to assess how densities of seals changed as a function of distance from shore. Satellite-linked time-depth recorders were attached to ringed seals in both years to evaluate the time spent basking on the ice surface. Haulout patterns indicated that ringed seals transitioned to basking behavior in late May and early June, and that the largest proportion of seals $(60-68 \%)$ was hauled out between 0830 and 1530 local solar time. Ringed seals were relatively common in nearshore fast ice and pack ice, with lower densities in offshore pack ice. The average density of ringed seals was 1.91 seals $\mathrm{km}^{-2}$ in 1999 (range $0.37-$ 16.32) and 1.62 seals $\mathrm{km}^{-2}$ in 2000 (range $0.42-19.4$ ), with the highest densities of ringed seals found in coastal waters south of Kivalina and near Kotzebue Sound. The estimated abundance of ringed seals for the entire study area was similar in $1999(252,488$ seals, $\mathrm{SE}=47,204)$ and $2000(208,857$ seals, $\mathrm{SE}=25,502)$. Bearded seals were generally more common in offshore pack ice, with the exception of high bearded seal numbers observed near the shore south of Kivalina. Bearded seal densities were not adjusted for haulout behavior, and therefore, abundance was not estimated. Unadjusted average bearded seal density was 0.07 seals $\mathrm{km}^{-2}$ in 1999 (range $0.011-0.393$ ) and 0.14 seals $\mathrm{km}^{-2}$ in 2000 (range 0.009
\end{abstract}

J. L. Bengtson $(\bowtie) \cdot$ L. M. Hiruki-Raring $\cdot$ M. A. Simpkins

P. L. Boveng

National Marine Mammal Laboratory,

Alaska Fisheries Science Center, NOAA Fisheries

NOAA, 7600 Sand Point Way NE,

Seattle, WA, 98115 USA

E-mail: john.bengtson@noaa.gov

Tel.: + 1-206-5264016

Fax: + 1-206-5266615
0.652). Levels of primary productivity, benthic biomass, and fast ice distribution may influence the distributions of ringed and bearded seals in the Chukchi Sea. Information on movement and haulout behavior of ringed and bearded seals would be very useful for designing future surveys.

\section{Introduction}

Ringed seals (Phoca hispida) are small phocid seals that are widely distributed throughout Arctic and sub-Arctic waters, usually associated with areas of seasonal sea ice (McLaren 1958a; Frost and Lowry 1981; Smith 1987; Kelly 1988; Heide-Jorgensen and Lydersen 1998). Bearded seals (Erignathus barbatus) also have a circumpolar distribution; in Alaska waters they occur in the Bering, Chukchi, and Beaufort Seas and generally select pack ice habitats located farther offshore than the shorefast and coastal pack ice habitats commonly utilized by ringed seals (Burns 1970, 1981; Kingsley and Stirling 1991). These two seal species are important to native subsistence harvests in the Arctic, and ringed seals are an important prey species for polar bears (Stirling and McEwan 1975; Smith 1980). Knowledge of ringed and bearded seal population dynamics, however, is limited in Alaskan waters (Angliss and Lodge 2002).

Ringed and bearded seals overwinter in areas of pack or shorefast sea ice, where they use lead systems and actively maintain breathing holes through the ice (Smith and Stirling 1978; Burns et al. 1981). During the winter, ringed seals convert some breathing holes to lairs by excavating the snow covering the breathing holes. Ringed seals use these lairs for resting and for the birth and nursing of their young in March-May (McLaren 1958a; Smith and Stirling 1975; Hammill and Smith 1989; Smith and Lydersen 1991; Furgal et al. 1996). Breathing holes and lairs are generally within $1-2 \mathrm{~km}$ of each other during the winter when seals' movements are 
constrained by the location of breathing holes in shorefast ice (Kelly and Quakenbush 1990). Most bearded seals remain in the pack ice through the winter as the sea ice expands southward into the Bering Sea (Burns 1981). Many of the bearded seals that winter in the Bering Sea migrate north through the Bering Strait and spend the summer along the ice edge in the Chukchi Sea, though some remain in open-water areas of the Bering and Chukchi Seas (Burns 1981).

In late spring, ringed and bearded seals haul out for their annual molt on the surface of the ice near breathing holes, lairs, or natural cracks or leads in the ice cover (Smith 1973; Smith and Hammill 1981; Burns 1981). Increased temperature and day length at this time of year promote higher skin temperatures, which facilitate epidermal growth (Feltz and Fay 1966). Because both species of seals are readily visible above the ice at this time, conditions are good for conducting aerial surveys of the local distribution and abundance of ringed and bearded seal populations. Although ringed seals have been surveyed recently in portions of the Bering Sea (Simpkins et al. 2003) and the Beaufort Sea (Frost et al. 1997, 1998, 1999), seal densities in the eastern Chukchi Sea have not been assessed since 1985-1987 (Frost et al. 1988). In addition, a correction factor is needed to account for seals that are not visible, and therefore not counted, during the survey because they are either in the water or in lairs under the snow.

This paper presents results from ringed and bearded seal surveys conducted in 1999-2000 in the eastern Chukchi Sea. We estimate ringed and bearded seal densities, a correction factor for ringed seal counts, and the abundance of ringed seals in the eastern Chukchi Sea. We also assess the offshore densities of ringed and bearded seals in the Chukchi Sea, in contrast to previous surveys (Frost et al. 1988) that concentrated on nearshore areas.

\section{Methods}

The scientific research reported here was conducted under the authorization of Marine Mammal Protection Act Permit No. 782-1355, issued to the National Marine Mammal Laboratory.

\section{Aerial surveys}

Aerial surveys were flown along the northwest coast of Alaska from 23 May 1999 to 6 June 1999 and 21-31 May 2000. The survey area covered the eastern Chukchi Sea coast from just north of Bering Strait to Pt. Barrow (Fig. 1), including the coastal zone and offshore habitats. In the coastal zone, transect lines of $37 \mathrm{~km}(20$ nautical miles) were flown at a speed of $167-185 \mathrm{~km} / \mathrm{h}$ (90-100 kt) and an altitude of $91 \mathrm{~m}$ (300 feet) on a course generally perpendicular to the shoreline. The coastal transect line length was chosen to match the length of lines from previous surveys (Frost et al. 1988). In addition, lines of 148-185 km (80-100 nautical miles) were flown to assess how seal densities changed as a function of distance from shore. The survey aircraft was a twin-engine Aero Commander, equipped with "bubble" windows to accommodate visual observations out to the side and down from the aircraft's position. Survey flights were conducted between 0730 and 1530 local solar time $(0730-1500$ in $1999 ; 0930-1530$ in 2000) to
Fig. 1 Survey lines and sampling strata for ringed and bearded seal surveys in A 1999 and B 2000 in the eastern Chukchi Sea. Note the open water lead that formed between the fast ice and pack ice offshore of Point Lay in both years. Most survey flights in the coastal strata near the lead were truncated at the fast ice edge (i.e., no pack ice was surveyed in those strata). The area inland from Kotzebue was not surveyed
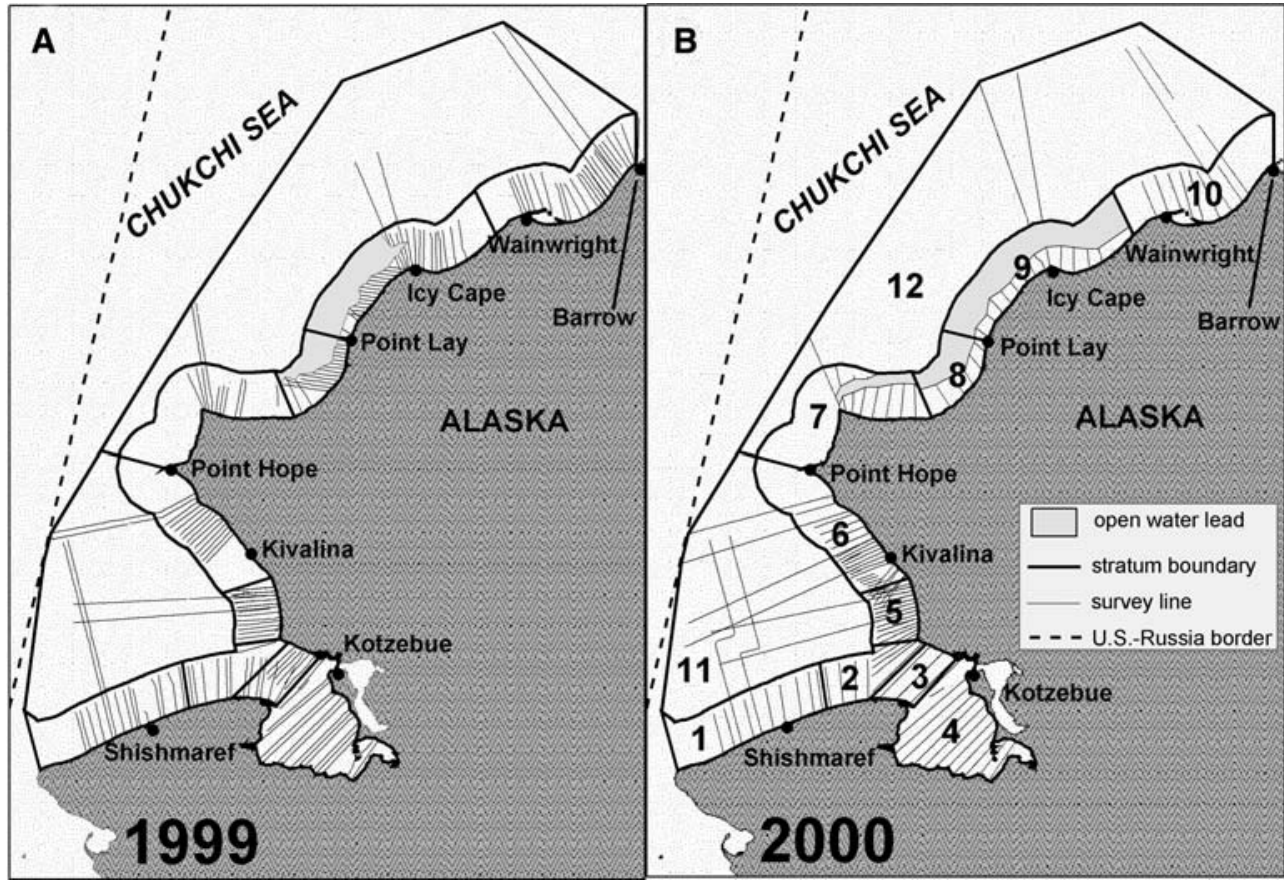
coincide with the time of day when the highest numbers of seals were expected to be hauled out (Burns and Harbo 1972; Smith and Hammill 1981; Krafft et al. 2000; Born et al. 2002). Two observers collected data during each flight: one each at windows on the right and left sides of the aircraft. Observers recorded the number and species of each observed group of seals hauled out on sea ice, and the transition from fast ice to pack ice on each survey line, using audiotapes and a video recorder.

For all surveys, we utilized line-transect survey methods (Buckland et al. 2001). For each observation, the perpendicular distance between the aircraft and seals was measured by sighting along six fixed vertical angles defined by marks on a plexiglass strip attached to the aircraft's window. Correct eye position relative to the marks was maintained by visually aligning a pair of marks on a plexiglass sighting board like a gunsight. The sighting board allowed seals to be quickly assigned to distance intervals, even in areas of high seal density, and allowed the observer's view to remain focused on the ice to avoid missing nearby seals.

To accommodate concerns raised by Alaska Natives who were hunting bowhead whales during our surveys, a 28-km (15 nautical miles) "no-fly" zone was maintained around the villages of Wales, Kivalina, Point Hope, Wainwright, and Barrow until whaling activities had been concluded. In 1999, whaling activities had concluded at Wainwright and Barrow by the time those areas were surveyed. In 2000, whaling activities were underway during the duration of the aerial surveys, but permission was granted by Kivalina hunters to conduct aerial surveys within the Kivalina no-fly zone during 2124 May 2000.

The survey area was divided into coastal and offshore strata (Fig. 1). The coastal stratum was defined as the area within $43 \mathrm{~km}$ (23 nautical miles) of the shore that included all observations from the coastal survey lines. The large open-water lead off the coast between Point Hope and Barrow was excluded when surveying the coastal stratum (Fig. 1) because seals were only recorded when they were hauled out on sea ice, which was not present in the lead. The offshore stratum was defined as the area from $43 \mathrm{~km}$ offshore to a minimum convex boundary that included all observations from the offshore survey lines. This offshore stratum was divided into northern and southern offshore strata with a boundary at Point Hope, where there was a distinct geographic break in our sampling caused by the no-fly zone around Point Hope.

The coastal stratum was subdivided into several strata based on the apparent density of ringed seals along the coast (Fig. 1). Proxy density values were calculated as the number of ringed seals observed per kilometer of effort for each survey line (actual density estimates were derived after the data had been stratified). These proxy values were adjusted for the effect of timeof-day on the proportion of seals hauled out, using the haulout behavior model derived from monitored seals (described below). The adjusted proxy values were used to stratify the survey area (Bering Strait to Barrow) into strata that were consistent for both years. First, the coastal survey area was divided into three strata with boundaries at Point Hope and Wainwright, where the no-fly zones caused distinct geographic breaks in our sampling. Next, high-density and very-high-density strata were defined for each year as clusters of survey lines with proxy-density values that were greater than 75 and $90 \%$ of the proxy-density values for that year, respectively. The resulting coastal strata were divided further into shore-fast ice and pack ice substrata based on ice conditions. These survey strata also allowed comparisons of ringed seal density estimates from this study with counts from 1985-1987 (Frost et al. 1988).

\section{Haulout behavior}

In 1999 and 2000, satellite-linked time-depth recorders (SLTDRs) (Wildlife Computers, Redmond, WA, USA) were deployed on six ringed seals to obtain detailed information on haulout behavior, which was used to correct aerial survey counts for seals that were not hauled out on ice (Table 1). In 1999, SLTDRs were deployed in collaboration with Dr. Brendan Kelly (University of Alaska Fairbanks) at his field site at Reindeer Island in northern Alaska $(11 \mathrm{~km}$ offshore from Prudhoe Bay). To capture ringed seals, seal breathing holes in the shorefast sea ice were located

Table 1 Ringed seals instrumented with satellite-linked time depth recorders at Reindeer Island, Beaufort Sea (1999), and Kotzebue Sound, Chukchi Sea (2000)

\begin{tabular}{llllll}
\hline Location & Sex & Length $(\mathrm{cm})$ & Mass $(\mathrm{kg})$ & Deployment date & $\begin{array}{c}\text { Dates when data were } \\
\text { obtained from basking seals }\end{array}$ \\
\hline Reindeer Island & $\mathrm{F}$ & $120^{*}$ & 50.0 & 6 May 1999 & 27 May-25 June 1999 \\
Reindeer Island & $\mathrm{F}$ & $123^{*}$ & 54.5 & 23 May 1999 & 2-20 June 1999 \\
Reindeer Island & $\mathrm{F}$ & $122^{*}$ & 52.3 & 24 May 1999 & 2-14 June 1999 \\
Kotzebue Sound & M & 91 & $21.8^{*}$ & 18 May 2000 & 20 May-24 June 2000 \\
Kotzebue Sound & M & 100 & $29.0^{*}$ & 20 May2000 & 22 May-14 June 2000 \\
Kotzebue Sound & M & 111 & $39.6^{*}$ & 20 May2000 & 22 May-6 June 2000 \\
\hline
\end{tabular}

Seal body size was measured by mass in 1999 and by total length in 2000. Corresponding $\left(^{*}\right)$ length and mass values were estimated using length-weight relationships from McLaren 1958b. The haulout model utilized data from seals after their onset of basking behavior in 1999; in 2000, all seals were instrumented after the onset of basking behavior 
using trained dogs, remotely-triggered nets were set up, and the breathing holes were continuously monitored using remote microphones (Kelly 1996). When a seal was heard at a monitored hole, the net was triggered remotely by radio, trapping the seal in the breathing hole above the pursed net.

In 2000, the capture net system was modified for use at breathing holes in the shorefast ice near Kotzebue, $\mathrm{AK}$, during the time of year when ringed seals are basking on the ice surface. These nets allowed seals to pass through their breathing holes and haul out (when the nets were open). Using a helicopter, we located breathing holes that appeared to be used regularly in coastal fast ice, and deployed nets at those holes. On subsequent days, we flew over each net site. If one or more seals were hauled out, we triggered the net to close via radio, blocking the hole and trapping the seal(s) on the surface of the ice. We then landed the helicopter and captured the seal(s) by hand. Usually, seals were attempting to escape down the breathing hole after we landed, so we simply pulled the seal(s) out of the hole by their hind flippers and manually restrained them while an SLTDR was glued to the hair on each seal's back with quick-setting epoxy. Location and haulout data were collected from the recorders via the ARGOS satellite system.

Ringed seal haulout behavior was modeled using "timeline" data from the SLTDRs. The timeline data were series of binary data collected every $20 \mathrm{~min}$, with "1" indicating that the SLTDR tag was wet for most of a 20-min sampling period and " 0 " indicating that the tag was dry for most of the period. For this analysis, we assumed that 1 indicated that a seal was in the water, and 0 indicated that a seal was hauled out, and visible, on the ice surface. We used only data collected during the "basking season," when most seals had switched to hauling out on the ice surface and were no longer hidden from view in snow-covered lairs. For 1999, the basking season was identified as the period of time following an abrupt change in ringed seal behavior from essentially random haulout behavior to strongly diel behavior with most haulout bouts occurring during mid-day (Table 1). This change in behavior closely matched the transition from lair use to surface basking, observed by Kelly et al. (2000) in a related study of ringed seal haulout behavior (the three seals tagged in 1999 were included in the sample of animals monitored by Kelly et al. 2000). In 2000 , the seals were captured while basking on the surface, and their behavior was already strongly diel; we included all data from those seals because the basking season had already begun (Table 1).

The timeline data from the basking seasons of both years were used to fit a model of haulout status as a function of time of day (local solar time). A generalized linear mixed-effects model (Splus function glmmPQL; Insightful Corporation, Seattle, WA, USA) was used to model the binary timeline data while including temporal autocorrelation and a random effect of variability among seals within the model (Venables and Ripley
2002). The binary timeline data were modeled using the logit link and binomial variance function (McCullagh and Nelder 1989), and temporal autocorrelation in the data was modeled using a linear correlation structure (range $=6.79 \mathrm{~h}$, nugget $=0.0603$ ), which provided the best fit to the data. The random effect of individual seal behavior was modeled as a random intercept value; the same diel haulout pattern (or curve) was fitted for all seals, but each seal could tend to haulout more, or less, frequently (higher or lower intercept). A random effect of day on individual seal behavior was also included in the model as a random intercept (i.e., each seal could tend to haul out more, or less, on any given day).

\section{Estimating seal densities}

Detection probabilities (probability of seeing a seal within the survey bins, if it was present) were estimated for each observer based on the recorded sighting data (not the proxy-density values mentioned above) of ringed and bearded seals hauled out on sea ice (using Distance 4.0, University of St. Andrews; Buckland et al. 2001). Ringed seal detection probabilities were estimated separately for observations on shore-fast ice and those on pack ice because sighting conditions were quite different in those two environments. Bearded seals were not seen frequently enough to estimate separate detection probabilities for each ice type, so all observations from each observer were used to estimate a "global" detection probability for that observer. Data from observers whose detection functions did not match the expected pattern (i.e., observers who saw fewer animals in the closest survey bin than were expected based on their observations in farther bins) were excluded from this analysis. Data from the farthest (sixth) sighting bin were excluded from analysis because we were not confident of species identifications in that bin.

Ringed and bearded seal densities were estimated based on the sightings recorded for all observers and the relevant detection probabilities. The resulting density estimates for ringed and bearded seals reflected the density of animals hauled out on the surface of the snow or ice. These "on-ice" densities for ringed seals were adjusted to actual densities by multiplying the on-ice density of seals for each survey line by the inverse of the haulout proportion predicted for the time of day at the midpoint of that line (this same procedure was used to adjust the proxy density values used in the stratification above). The bearded seal sighting densities presented in this paper were not adjusted for haulout proportions because of insufficient information about bearded seal haulout patterns. Aside from haulout information for lactating bearded seals in May near Svalbard, Norway (Krafft et al. 2000), we are not aware of any relevant bearded seal haulout data that would allow us to confidently adjust the on-ice densities observed during this study.

The abundance of seals in each stratum was calculated as the sum of the abundance estimates for each line 
multiplied by the ratio of stratum area to survey effort within the stratum. The density of seals in each stratum was simply the abundance estimate divided by the stratum area. The variances of density and abundance estimates were derived using a modification of the deltamethod that included the variance due to differences in estimates between survey lines (Innes et al. 2002).

\section{Results}

\section{Aerial surveys}

The total study area was different in 1999 and 2000 due to changes in the size of the recurrent open-water lead off the coast north of Point Hope (strata 7, 8, and 9; Fig. 1). We did not include the open water lead in our survey area because we did not count animals in the water. In both 1999 and 2000, the timing of the survey coincided with ringed seals' transition to basking behavior (Table 1). In 1999, seals tagged with SLTDRs in the northern portion of the survey area (near Reindeer Island in the Beaufort Sea) were first observed basking during 21 May-2 June 1999 (Kelly et al. 2000), while surveys were conducted during 23 May-6 June 1999. We started surveying in the southern part of the study area, where ringed seals presumably started basking earlier than the tagged seals in the north. In 2000, all captured seals were already basking when they were captured during 18-20 May in the southern portion

Fig. 2 Predicted haulout proportions of ringed seals throughout the day in May-June (as calculated from "timeline" data from satellite-linked time-depth recorders deployed on ringed seals). Thin lines bracketing the heavy line indicate one standard error above and below the haulout curve of the study area (near Kotzebue Sound), while surveys were conducted during 21-31 May 2000.

\section{Haulout behavior}

The six satellite-linked time-depth recorders that were deployed on ringed seals (Table 1) monitored the seals' dive and haulout behavior through June. The termination of transmissions occurred at about the time when we would have expected the transmitters to fall off of the seals at the completion of their molt cycle. The "timeline" data from these instruments were used to estimate a daily haulout curve for ringed seals during the survey period (Fig. 2). The residual variance was evaluated to estimate a random effect of individual seal behavior on the model and a random effect of day on individual seal behavior. The values of these two random effects (presented as standard errors) were 0.652 (seal effect) and 0.0299 (day effect for each seal), leaving 1.161 unexplained residual variance. The inverse of the predicted haulout proportion for any given time was used to adjust ringed seal density and abundance estimates for survey lines flown at that time. All survey data from both years were collected during the mid-day period when greater than $60 \%$ of ringed seals were predicted to be basking on the ice (maximum of $68 \%$ near local solar noon), except for data from some early flights in $1999(10 \%$ of the 1999 flights were flown between 0730 and 0830 , when $57-61 \%$ of seals were predicted to be basking).

\section{Seal densities}

Ringed seals were relatively common in most coastal areas (Table 2, Fig. 3), with an average density of 1.91

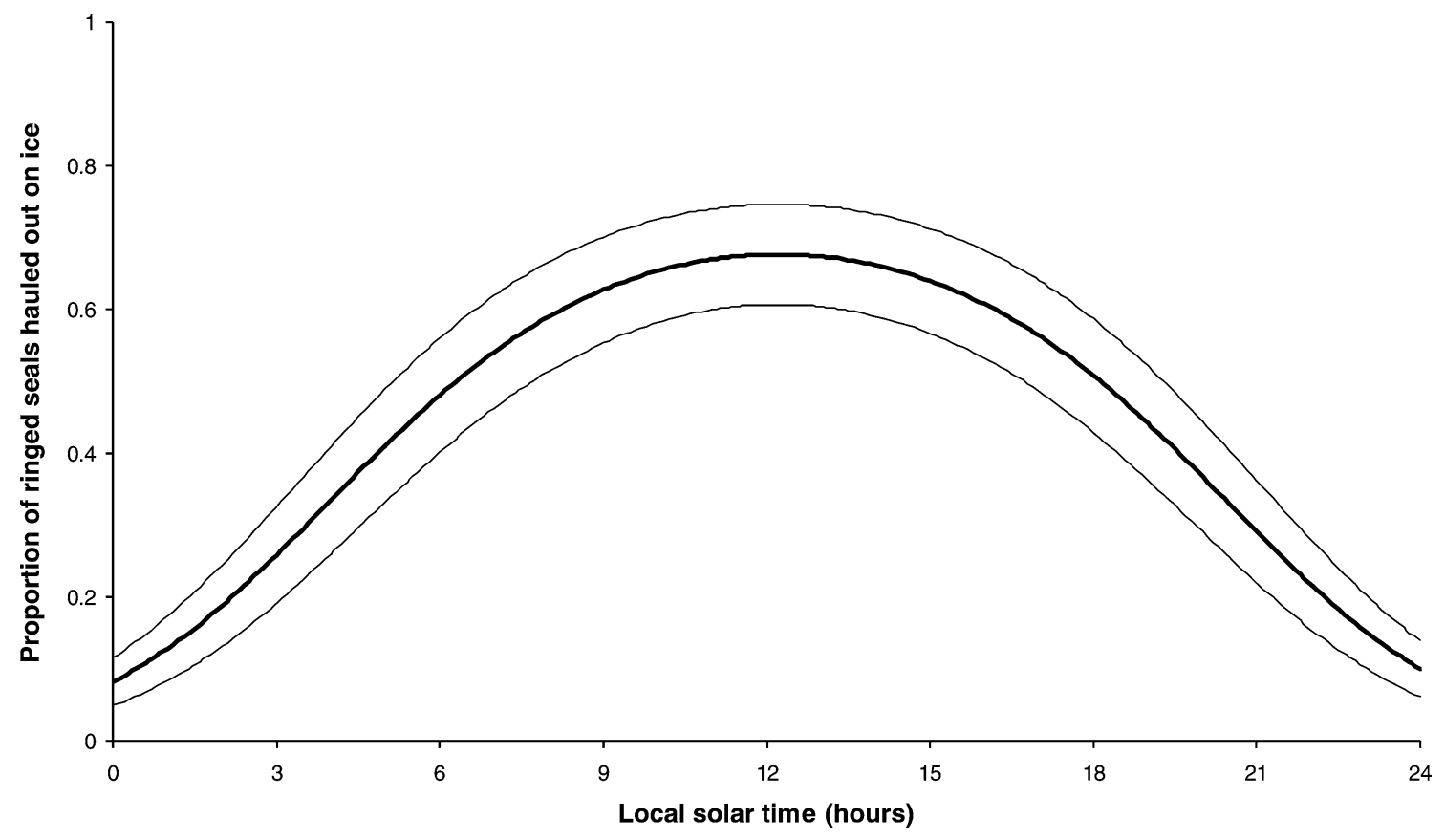


Table 2 Ringed seal densities (adjusted for survey timing and seal haulout behavior) observed in the eastern Chukchi Sea, 1999-2000 $(\mathrm{SE}=$ standard error $)$

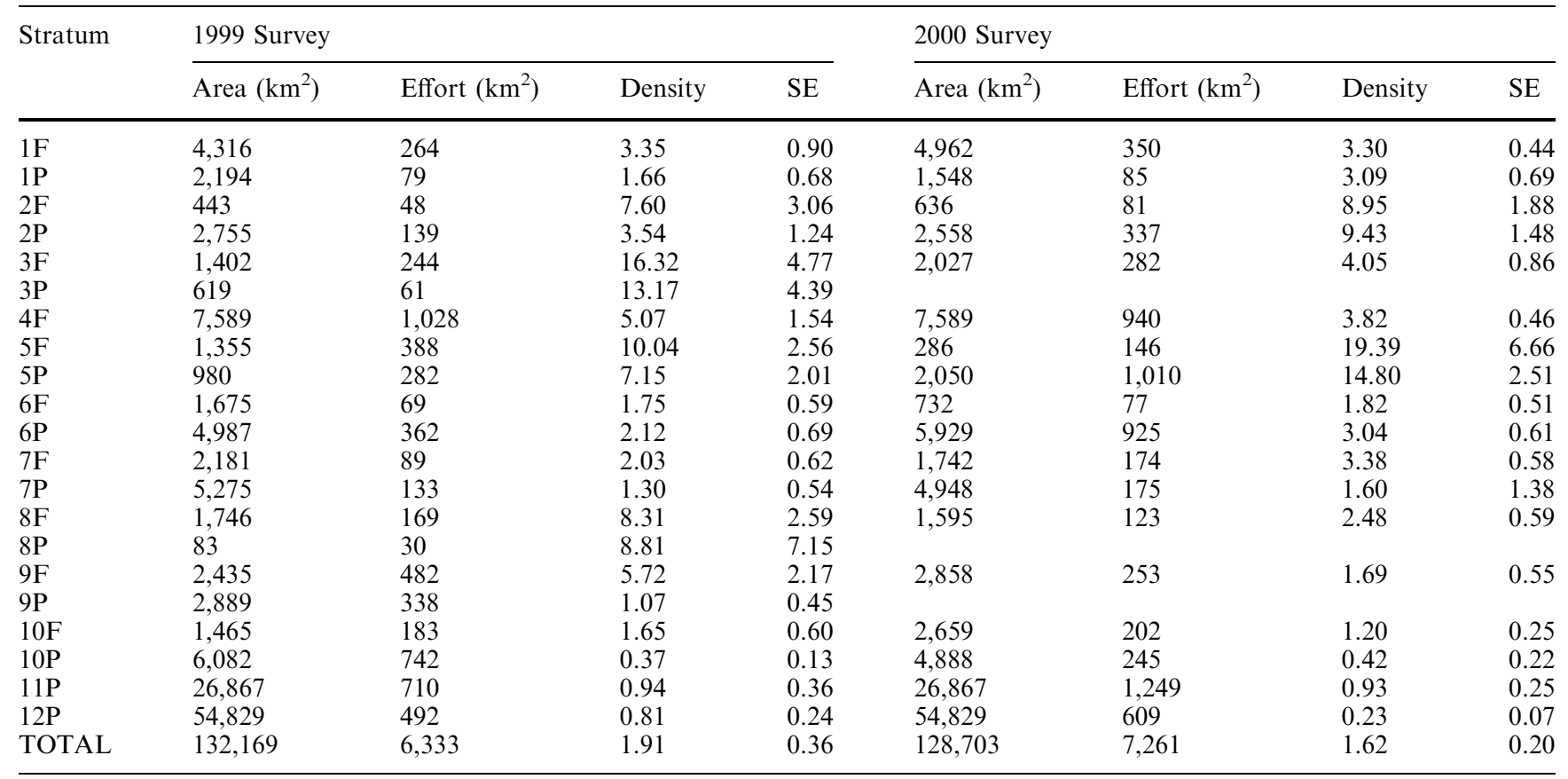

Strata designated with a $\mathrm{F}$ are fast ice; $\mathrm{P}$ are pack ice; and $11 \mathrm{P}$ and $12 \mathrm{P}$ are offshore pack ice. In 2000, pack ice was not present in stratum 3, and strata 8P and 9P coincided with the seasonal open-

seals $\mathrm{km}^{-2}$ in 1999 (range 0.37-16.32) and 1.62 seals $\mathrm{km}^{-2}$ in 2000 (range $0.42-19.4$ ). The highest densities of ringed seals were encountered on shorefast ice along the coast and in Kotzebue Sound, as well as in pack ice habitats within $43 \mathrm{~km}$ of the shore. In both 1999 and 2000, the highest densities of ringed seals were water lead shown in Fig. 1. Survey effort was calculated based on the effective strip width (Buckland et al. 2001) and length of survey lines surveyed by each observer
Fig. 3 Estimated densities of ringed seals in the eastern Chukchi Sea in May-June in A 1999 and B 2000. Density estimates have been adjusted for the proportion of seals predicted to be hauled out on ice during the aerial surveys. The area inland from Kotzebue was not surveyed. For simplicity, the open water lead shown in Fig. 1 is not depicted here, but the lead was excluded when estimating the densities shown here
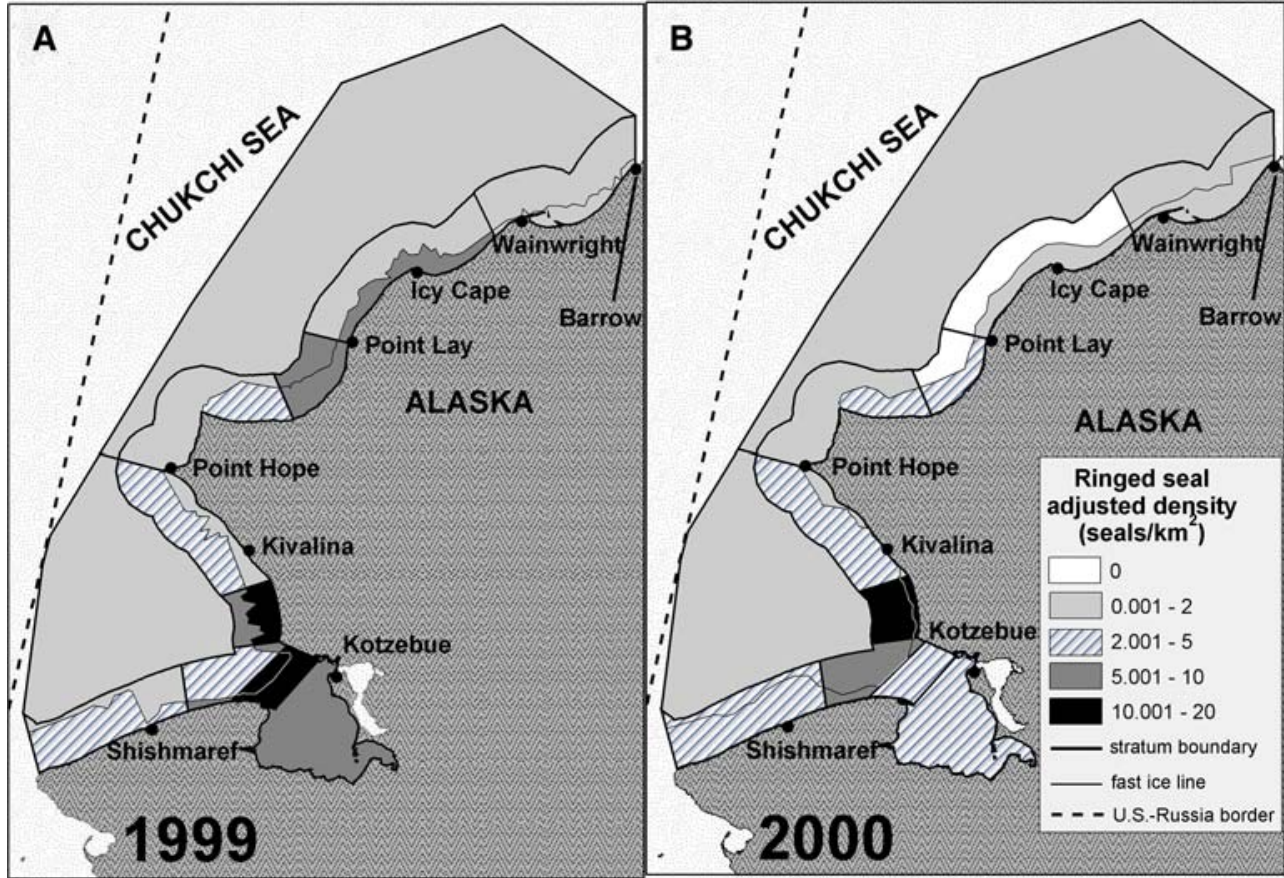
Fig. 4 Density of $\mathbf{A}$ ringed and B bearded seals as a function of sea-ice habitat and distance from shore (error bars $=$ one standard error). Ringed seal densities have been adjusted for the proportion of seals predicted to be hauled out on ice during aerial surveys; bearded seal densities are unadjusted for survey timing and seal haulout behavior
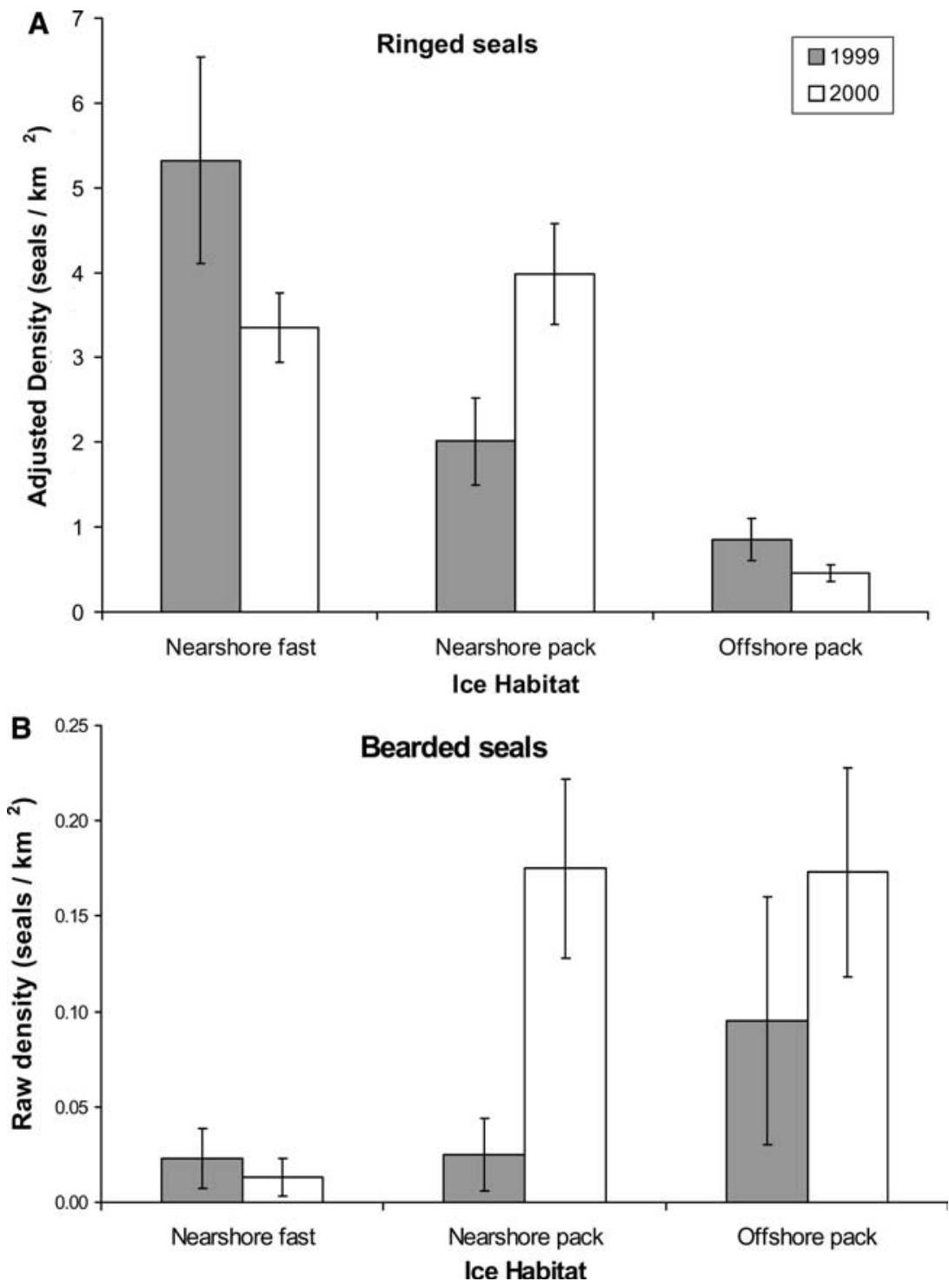

Although ringed seal densities in most strata varied markedly between 1999 and 2000, the estimated abundance of ringed seals for the entire study area was fairly similar in $1999 \quad(252,488, \quad \mathrm{SE}=47,204)$ and 2000 $(208,857, \mathrm{SE}=25,502)$.

Bearded seals were observed less frequently than ringed seals throughout most of the study area, with an average density (uncorrected for haulout behavior) of 0.07 seals km$~^{-2}$ in 1999 (range $0-0.393$ ) and 0.14 seals $\mathrm{km}^{-2}$ in 2000 (range $0-0.652$ ) (Table 3, Fig. 6). Bearded seal densities were highest in offshore pack ice in both 1999 and 2000 (Fig. 4b). Although bearded seals were generally absent in the interior expanses of fast ice, they hauled out on fast ice at its interface with pack ice in some strata, or along open cracks in the fast ice. Bearded seals were more common in the southern region of the study area than the northern region (Fig. 5b), as reflected in the relatively high densities of bearded seals encountered along the coast to the south of Kivalina in both years (Fig. 6).
Although we generally surveyed different areas each day (in order to efficiently cover the entire study area), we did deliberately survey a small region near Kivalina three times in 2000. Ringed seal density estimates from the first two surveys were similar, but density increased dramatically in the third survey (up to 20 times higher than earlier estimates). This increase in density seemed related to exceptionally good weather conditions during that survey (sunny with clear skies and low wind) compared with cloudy and foggy weather during the previous surveys.

\section{Discussion}

Density and abundance estimates

Ringed seals were relatively common in the eastern Chukchi Sea, with an average density of 1.91 seals km$~^{-2}$ in 1999 and 1.62 seals km kn $^{-2}$ in 2000 
Fig. 5 Density of $\mathbf{A}$ ringed and B bearded seals in the northern (north of Point Hope) and southern (south of Point Hope) regions of the study area (error bars $=$ one standard error). Ringed seal densities have been adjusted for the proportion of seals predicted to be hauled out on ice during aerial surveys; bearded seal densities are unadjusted for survey timing and seal haulout behavior
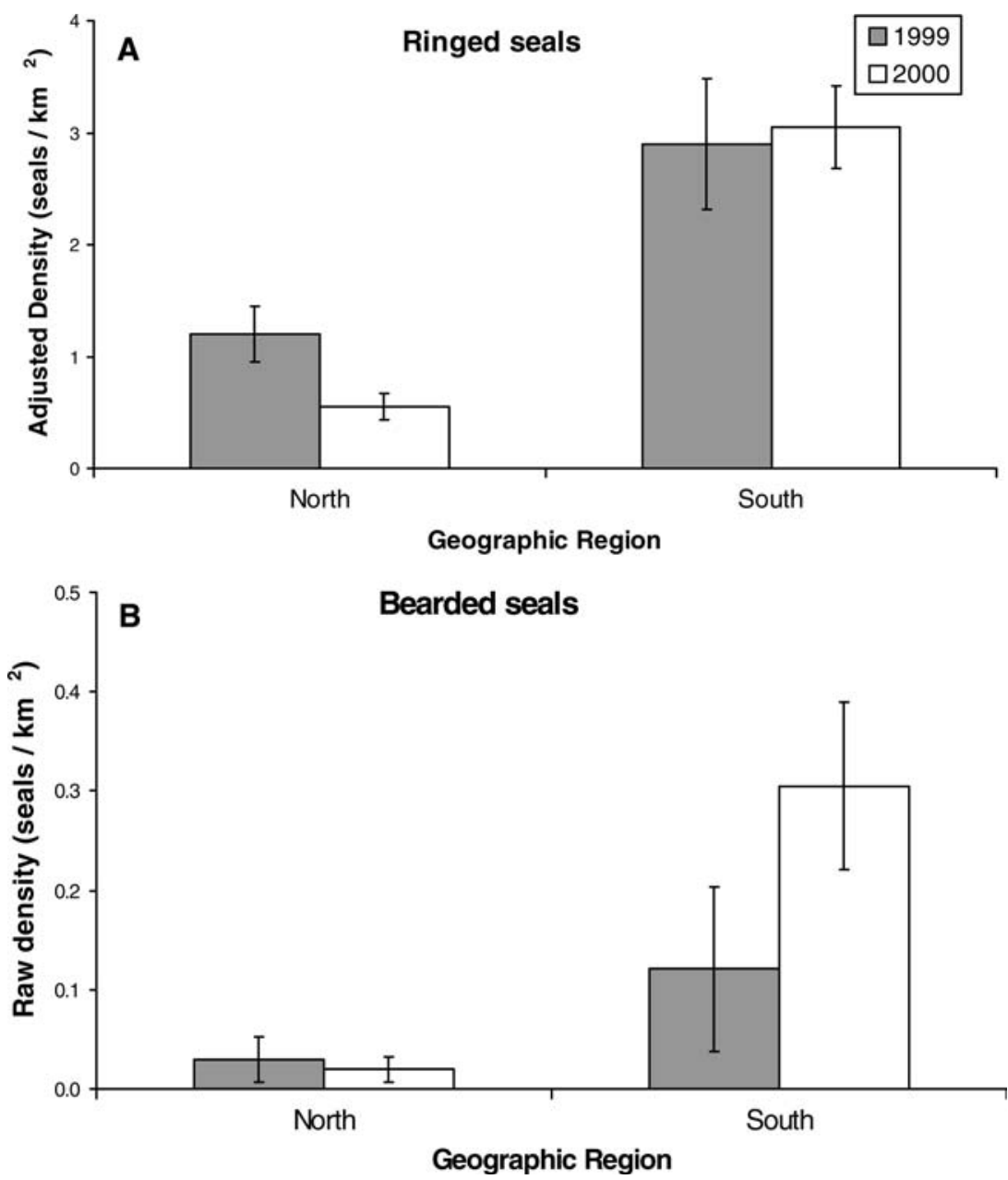

(Table 2). Bearded seals were observed less frequently than ringed seals, with an average density of $0.07 \mathrm{~km}^{-2}$ in 1999 and 0.14 seals km $\mathrm{km}^{-2}$ in 2000 (Table 3). Although the distribution of ringed seals varied between 1999 and 2000 (Fig. 3), the estimated total abundance of ringed seals was similar (about 200,000 250,000 seals).

The haulout behavior model created for ringed seals was used to adjust survey data for the effect of time of day on ringed seals. However, there were some shortcomings in applying this correction. The small sample size of monitored seals prevented us from determining any age and sex differences in haulout behavior. Also, this correction only adjusts for animals in the water and assumes that, when seals haul out, they bask on the ice surface rather than in snowcovered lairs. In 1999, the behavioral transition to basking was observed in the haulout behavior of monitored seals between 27 May and 2 June, which was approximately the middle of the survey (23 May6 June). The monitored seals were near the northern end of the survey area, which was surveyed last (i.e., after the monitored seals had begun basking). More southerly seals presumably began basking earlier, and we assumed that the majority of seals were no longer using lairs when we surveyed their region. In 2000, seals were captured while basking at the southern end of the survey area (18-20 May), prior to the survey (21-31 May). Although it is possible that more northerly seals had not fully transitioned to basking, the large numbers of seals observed indicated that many seals were basking when we surveyed their region. Also, in both years, melt pools were commonly seen on the ice throughout the survey area, suggesting that the snow had begun to melt, making lairs less stable and suggesting that seals probably were no longer using lairs. If some fraction of ringed seals were using lairs during our surveys, both density and abundance estimates would be underestimated by that fraction, resulting in conservative estimates. These conservative estimates, however, do account for the proportion of "basking seals" that were not seen because they were in the water during the survey. Therefore, the adjusted estimates are more accurate than unadjusted estimates of observed ringed seal densities, which dramatically underestimate the actual densities of seals and ignore the effect of time of day on the observed density of seals. 
Table 3 Bearded seal densities (unadjusted for survey timing and seal haulout behavior) in the eastern Chukchi Sea, 1999-2000 $(\mathrm{SE}=$ standard error $)$

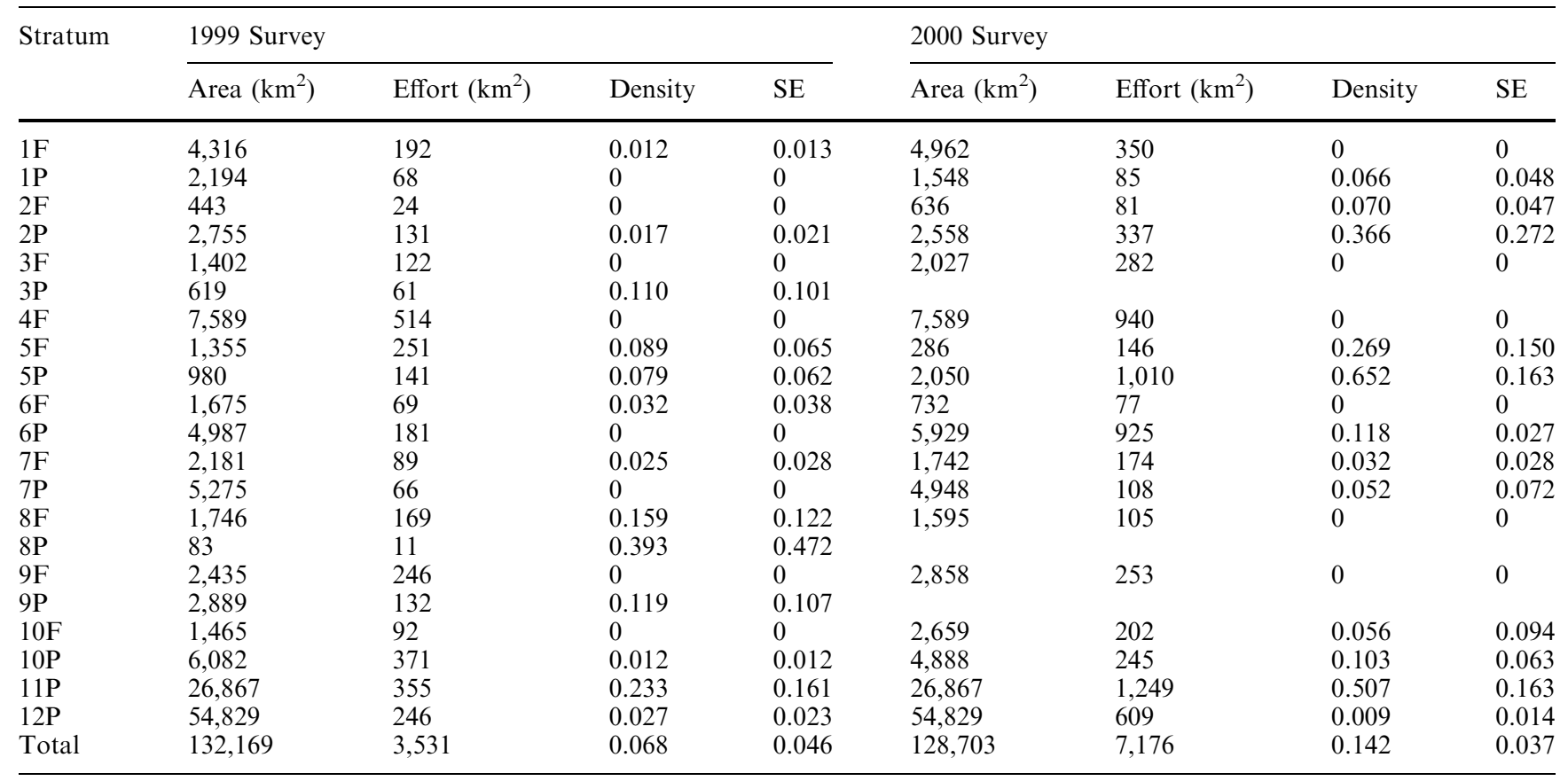

Strata designated with a $\mathrm{F}$ are fast ice; $\mathrm{P}$ are pack ice; and $11 \mathrm{P}$ and $12 \mathrm{P}$ are offshore pack ice. In 2000, pack ice was not present in stratum 3, and strata 8P and 9P coincided with the seasonal openwater lead shown in Fig. 1. Survey effort was calculated based on the effective strip width (Buckland et al. 2001) and length of survey lines surveyed by each observer. Data were excluded for some observers, resulting in lower survey effort in 1999
A larger sample size of monitored animals and longer deployments of instruments would improve our understanding of haulout behavior and thus increase our confidence in correction factors for haulout behavior, and might also shed light on site fidelity of seals during molting. Studies presently underway to investigate haulout and basking behavior of ringed seals in relation to snow melt (Kelly et al. 2000) should improve our
Fig. 6 Estimated densities of bearded seals (unadjusted for survey timing and seal haulout behavior) in the eastern Chukchi Sea in May-June in A 1999 and B 2000. The area inland from Kotzebue was not surveyed. For simplicity, the open water lead shown in Fig. 1 is not depicted here, but the lead was excluded when estimating the densities shown here
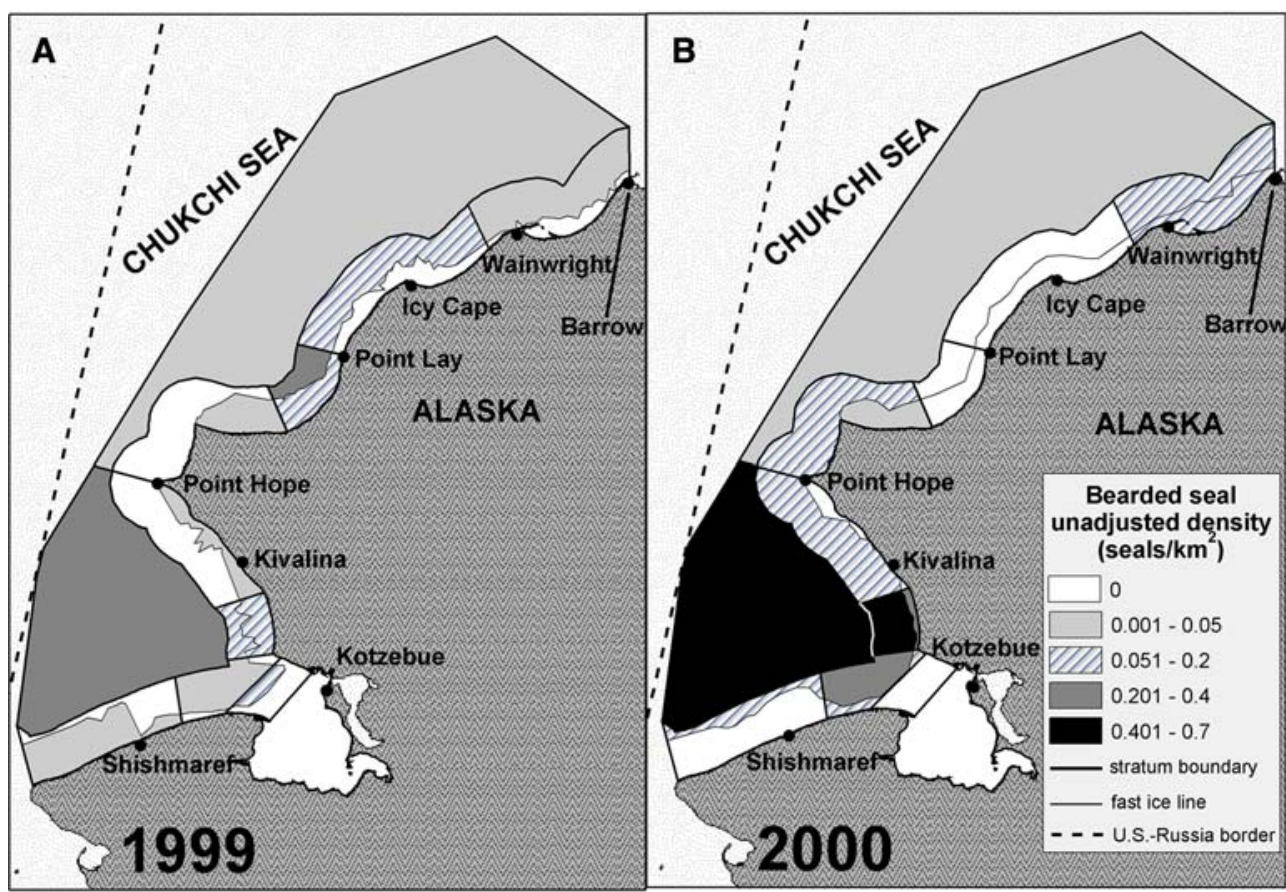
ability to identify the basking season and estimate a correction factor for seals not counted on aerial surveys.

Bearded seal densities were not corrected for haulout behavior because of insufficient information on the haulout patterns of bearded seals, and therefore the abundance of bearded seals in the eastern Chukchi Sea was not estimated. The uncorrected densities presented here may dramatically underestimate actual bearded seal densities because a correction factor to account for seals in the water could be as high as 12.5 (based on haulout proportions estimated by Krafft et al. 2000). Current studies of bearded seals in the Chukchi Sea (Cameron et al. 2005) may soon provide the detailed information on haulout behavior and movements needed to provide an accurate correction factor for bearded seal surveys.

\section{Ice habitats}

There was a pronounced difference in the relative densities of ringed and bearded seals hauled out in nearshore and offshore sea-ice habitats (Fig. 4). Ringed seals were four to ten times more abundant in nearshore fast and pack ice environments than in offshore pack ice. This distribution is consistent with the pattern reported by other authors such as Smith (1973), who reported that densities of ringed seals were much lower beyond $29 \mathrm{~km}$ from shore. The higher densities of ringed seals in the coastal areas was not surprising, given the importance of shorefast ice for ringed seal lairs and breeding habitat (Burns 1970; Smith and Stirling 1975; Smith and Hammill 1981; Lydersen and Gjertz 1986; Hammill and Smith 1989; Lydersen et al. 1990; Lydersen and Ryg 1991; Smith et al. 1991; Furgal et al. 1996). In contrast to ringed seals, bearded seal density was lowest in nearshore fast ice and highest in offshore pack ice (Fig. 4), which was also expected, based on previous studies (Burns 1981). Ringed and bearded seals' preferences for nearshore or offshore habitat was independent of water depth; the Chukchi Sea is consistently shallow $(15-65 \mathrm{~m})$ with only one area of deeper water in the study area (80-150 m, stratum 10, Fig. 1), which did not appear to influence the distribution of seals.

\section{Regional differences}

Both ringed and bearded seals were observed in higher densities in the southern region of the study area (Fig. 5). It seems likely that their higher densities were related to enhanced biological productivity and prey availability south of Point Hope. Nutrient-rich waters flow north from the Bering Sea through Bering Strait to the southern Chukchi Sea (Grebmeier et al. 1989, 1990). These waters, in turn, support high rates of primary production (250-300 $\mathrm{g} \mathrm{C} \mathrm{m}^{-2}$ year $^{-1}$ compared to 10 $25 \mathrm{~g} \mathrm{C} \mathrm{m}^{-2}$ year $^{-1}$ in the Beaufort Sea), most of which settles out of the water column without being grazed by zooplankton; this rapid settling rate supports a high detritus-based benthic biomass (Grebmeier et al. 1988; Dunton et al. 1989). Benthic biomass in the southern offshore area of the Chukchi Sea can be as high as $68 \mathrm{~g}$ $\mathrm{C} \mathrm{m}^{-2}$ in contrast to less than $20 \mathrm{~g} \mathrm{C} \mathrm{m}^{-2}$ in areas north of Point Hope (Grebmeier and Dunton 2000). The higher benthic biomass in the southern Chukchi Sea supports a higher density of bearded seals, which are benthic predators (Burns et al. 1981; Smith 1981). Benthic communities differ between the coastal waters and offshore zones in the southern Chukchi Sea (Stoker 1981; Grebmeier et al. 1989), with low biomass of polychaetes, bivalves, and echiuroids coastally, and high biomass of amphipods and various bivalve species offshore. The predominantly offshore distribution of bearded seals likely reflects the higher biomass of benthic prey available to the seals.

Ringed seals in the southern Chukchi Sea prey primarily upon benthic crustaceans and saffron cod (E. gracilis) during May-July (Lowry et al. 1980). The high productivity of the southern Chukchi Sea seems to attract the higher density of ringed seals south of Point Hope. Prey availability, however, may not control the distribution of ringed seals during our May-June survey period. During this time, the breeding season is drawing to a close as the molting season begins, and the lactation period is ending as females wean their pups (Kelly 1988). Although ringed seals do forage throughout this time frame, they do so much less vigorously than during the winter and tend to lose weight from March to September (McLaren 1958b; Lowry et al. 1980).

Both bearded and ringed seals were observed in high densities in the coastal stratum south of Kivalina (stratum 5, Fig. 1) in both survey years (Figs. 3 and 6). Traditional knowledge of Alaska Native subsistence hunters also indicates that this area hosted a high density of bearded seals historically, and the area continues to be favored by subsistence hunters today (Enoch Shiedt, Kotzebue, AK, personal communication). Although the ecological conditions that foster high seal densities in this area are not known, benthic surveys indicate that benthic prey such as clams and shrimp are abundant in the area (Feder and Jewett 1978; Feder et al. 1992).

\section{Inter-annual comparisons}

Ringed seal densities were similar in 1999 and 2000; however, the density of bearded seals in 2000 was twice as high as in 1999 in the southern offshore stratum of the study area. Bearded seal densities were not corrected for the proportion of seals not hauled out during the surveys, so interannual differences may be caused, in part, by differences in haulout conditions for bearded seals. Interannual variability in local densities of ringed and bearded seals could reflect actual changes in the abundance of animals, changes in the distribution of animals, or a combination of the two. Distributional changes could be caused by interannual variation in ice condi- 
tions or prey distribution and abundance. Ice conditions, in particular, are likely to have a strong impact on the movements and distribution of ringed and bearded seals (e.g., Burns et al. 1981; Simpkins et al. 2003). The distributions of these two ice-associated species likely are affected by the timing of fast ice formation and the advance of pack ice, the areal extent of fast ice and pack ice, and the relative concentration of pack ice (i.e., percent of open water within the pack ice). Ongoing changes in the Arctic climate may cause directional shifts in snow or ice coverage (e.g., Johannesen et al. 1999; Vinnikov et al. 1999) and may even alter the distribution of prey species, especially Arctic cod (Boreogadus spp.), which are important prey for ringed seals through much of the year and are constrained by water temperatures (Wyllie-Echeverria and Wooster 1998).

Movements of seals between the Chukchi Sea and other areas may also affect densities. Ringed seals instrumented in the Canadian Arctic in the fall of 2001 and 2002 traveled up to $2,500 \mathrm{~km}$ in 6 weeks, moving westward to the Chukchi Sea and Eastern Siberian Sea (Harwood and Smith 2003). These long-distance migrations make it difficult to draw reliable conclusions on population trends in the broader population of ringed seals (Smith 1987, Harwood and Smith 2003). More information on seasonal and interannual movements and distribution of seals would help to interpret interannual differences in survey results.

The densities of ringed seals observed in this study were generally much higher than those reported from surveys in the 1980s (Frost et al. 1988; Table 4). Survey estimates from the 1980s did not correct for the proportion of seals not hauled out during the survey. The apparent difference in unadjusted ringed seal densities between the 1980s and 1999-2000 surveys (Table 4) may reflect differences in haulout conditions between the two survey periods. In particular, changes in the timing of the survey relative to the basking season in each survey year could strongly influence uncorrected density estimates. Although the surveys in the 1980s and the 1999 2000 surveys were conducted during the same calendar period (mid-May to mid-June), the ice and haulout conditions relative to the calendar dates could be different from year to year. Even estimates corrected for haulout behavior could be misleading if the survey occurred prior to the basking season, when ringed seals haul out in snow-covered lairs and are not visible to aerial observers (Kelly et al. 2000).

Other factors could also contribute to the apparent differences between the 1980s and 1999-2000 surveys, including methodological differences between the two survey efforts. The early surveys used strip transect methods, which assume that $100 \%$ of seals are seen within the survey zone; but double-counting experiments revealed that experienced observers were only spotting about $82 \%$ of the seals hauled out (Frost et al. 1988). The 1999-2000 surveys used line transect methods, in which more sighting effort is made in the area closer to the sighting platform, and sighting probabilities are used
Table 4 Inter-annual comparisons of unadjusted ringed seal densities (seals hauled out per $\mathrm{km}^{2}$ ) by survey sector in the eastern Chukchi Sea

\begin{tabular}{|c|c|c|c|c|c|c|}
\hline \multicolumn{4}{|c|}{ Frost et al. 1988} & \multicolumn{3}{|l|}{ This study } \\
\hline Survey sector & 1985 & 1986 & 1987 & Survey stratum & 1999 & 2000 \\
\hline $\mathrm{C} 1$ & 1.16 & 2.20 & 1.14 & $3 \mathrm{~F}, 4 \mathrm{~F}$ & 4.40 & 2.55 \\
\hline $\mathrm{C} 2$ & 1.08 & 1.57 & 1.33 & $5 \mathrm{~F}, 6 \mathrm{~F}$ & 3.59 & 4.47 \\
\hline $\mathrm{C} 4$ & 1.35 & 1.99 & 1.11 & $7 F, 8 \mathrm{~F}$ & 3.07 & 2.13 \\
\hline C5 & 0.78 & 1.05 & 0.76 & $9 \mathrm{~F}$ & 3.73 & 1.11 \\
\hline C6 & 0.71 & 1.17 & 0.79 & $10 \mathrm{~F}$ & 1.10 & 0.80 \\
\hline Averages & 1.10 & 1.77 & 1.06 & & 3.69 & 2.13 \\
\hline
\end{tabular}

No variances or standard errors are given because Frost et al. (1988) used strip-transect methods, which assumed 100\% sighting probability, and we used line-transect methods, which included sighting probability variance in our total variance estimate

to correct for seals that might have been missed at greater distances. In addition, the 1999-2000 surveys were flown at a slower speed $\left(167-185 \mathrm{~km} \mathrm{~h}^{-1}\right.$ vs $240 \mathrm{~km} \mathrm{~h}^{-1}$ in the 1980s), which could have increased the proportion of seals seen by observers compared to the earlier surveys. In general, strip transect surveys would be expected to estimate lower seal densities than line transect surveys, which correct for seals that might have been missed.

The interannual variability in ringed seal densities also may reflect actual changes in local ringed seal abundance caused by fluctuations in broad-scale weather and ice patterns, such as years with heavy or light snow cover or years with dramatically different seasonal ice coverage (Stirling et al. 1982; Lydersen and Ryg 1991; Smith and Lydersen 1991). Changes in ice and snow coverage could cause changes in population size, especially as a result of lower pup survival. Ringed and bearded seal densities also varied daily in the 1999-2000 surveys, presumably in response to day-to-day changes in haulout conditions, such as cloud cover, air temperature and wind speed. We found that ringed seal density estimates could change up to 20 -fold with substantial changes in weather conditions in a high-density region. Daily changes in haulout conditions were not explicitly modeled within our analysis, though these changes were implicitly included in the haulout model by the random effect modeled for day on the haulout behavior of individual seals.

Acknowledgments We are grateful to Kristin Laidre, Caleb Pungowiyi, and Enoch Shiedt for help with conducting the aerial surveys. Brendan Kelly and his field crew generously shared their field camp and extensive knowledge of ringed seals and capture methods, and helped us with instrumentation of ringed seals in 1999 and net modifications in 2000. Jeff Laake provided expert assistance with data analyses, and Ronda Hinz helped with data processing. We thank Dave Weintraub and the late Tom Blaesing (Commander Northwest, Wenatchee, WA) and Ed Gunter (Northwest Aviation, Kotzebue, AK) for their capable piloting skills. Leslie Kerr and the staff of the U.S. Fish and Wildlife Service's Selawik National Wildlife Refuge graciously provided lodging and logistical assistance in Kotzebue. This manuscript was improved by comments from M. Cameron, V. Burkanov, and three anonymous reviewers. 


\section{References}

Angliss RP, Lodge KL (2002) Alaska marine mammal stock assessments, 2002. US Dep Commer, NOAA Tech Memo NMFS-AFSC-133, pp 1-224

Born EW, Teilmann J, Riget F (2002) Haul-out activity of ringed seals (Phoca hispida) determined from satellite telemetry. Mar Mammal Sci 18:167-181

Buckland ST, Anderson DR, Burnham KP, Laake JL, Borchers DL, Thomas L (2001) Introduction to distance sampling: estimating abundance of biological populations. Oxford University Press, Oxford

Burns JJ (1970) Remarks on the distribution and natural history of pagophilic pinnipeds in the Bering and Chukchi Seas. J Mammal 51:445-454

Burns JJ (1981) Bearded seal-Erignathus barbatus Erxleben, 1777. In: Ridgway SH, Harrison RJ (eds) Handbook of marine mammals, vol 2 seals. Academic, New York, pp 145-170

Burns JJ, Harbo SJ Jr (1972) An aerial census of ringed seals, northern coast of Alaska. Arctic 25:279-290

Burns JJ, Shapiro LH, Fay FH (1981) Ice as marine mammal habitat in the Bering Sea. In: Hood DW, Calder JA (eds) The eastern Bering Sea shelf: oceanography and resources, vol 2. University of Washington Press, Seattle, pp 781-804

Cameron MF, Whiting A, Frost K, Lowry L, Goodwin J, Schaeffer C, Delong R, Sheffield G (2005) Winter movements of female bearded seals (Erignathus barbatus) in Kotzebue Sound and the Chukchi Sea. Abstract in: Marine Science in Alaska 2005, Anchorage, January 24-26, p 103

Dunton KH, Saupe SM, Golikov AN, Schell DM, Schonberg SV (1989) Trophic relationships and isotopic gradients among arctic and subarctic marine fauna. Mar Ecol Prog Ser 56:89-97

Feder HM, Jewett SC (1978) Survey of the epifaunal invertebrates of Norton Sound, the southeastern Chukchi Sea, and Kotzebue Sound. Report R78-1, Inst Mar Sci, University of Alaska, Fairbanks, pp 1-124

Feder HM, Naidu AS, Baskaran M, Frost KJ, Hameedi JM, Jewett SC, Johnson WR, Raymond J, Schell D (1992) Bering StraitHope Basin: habitat utilization and ecological characterization. Report 92-2, Inst Mar Sci, University of Alaska, Fairbanks, pp $1-465$

Feltz ET, Fay FH (1966) Thermal requirements in vitro of epidermal cells from seals. Cryobiology 3:261-264

Frost KJ, Lowry LF (1981) Ringed, Baikal, and Caspian seals. In: Effects of industrial activities on ringed seals in Alaska, as indicated by aerial surveys. In: Ridgway SH and Harrison RJ (eds) Handbook of marine mammals, vol 2 seals. Academic, London, pp 29-53

Frost KJ, Lowry LF, Gilbert JR, Burns JJ (1988) Ringed seal monitoring: relationships of distribution and abundance to habitat attributes and industrial activities. US Department of Commerce, NOAA, OCSEAP Final Report 61, pp 345-445

Frost KJ, Lowry LF, Hills S, Pendleton G, DeMaster DP (1997) Monitoring distribution and abundance of ringed seals in northern Alaska. Interim Rept. May 1996-March 1997, US Department of Interior Minerals Management Service, Cooperative Agreement 14-35-0001-30810, pp 1-42

Frost KJ, Lowry LF, Hills S, Pendleton G, DeMaster DP (1998) Monitoring distribution and abundance of ringed seals in northern Alaska. Interim Rept. April 1997-March 1998, US Department of Interior Minerals Management Service, Cooperative Agreement 14-35-0001-30810, pp 1-48

Frost KJ, Lowry LF, Hessinger C, Pendleton G, DeMaster DP, Hills S (1999) Monitoring distribution and abundance of ringed seals in northern Alaska. Interim Rept. April 1998-March 1999, US Department Interior Minerals Management Service, Cooperative Agreement 14-35-0001-30810, pp 1-37

Furgal CM, Innes S, Kovacs KM (1996) Characteristics of ringed seal, Phoca hispida, subnivean structures and breeding habitat and their effects on predation. Can J Zool 74:858-874
Grebmeier JM, Dunton KH (2000) Benthic processes in the northern Bering/Chukchi Seas: status and global change. In: Huntingdon HP (ed) Impacts of changes in sea ice and other environmental parameters in the arctic. US Marine Mammal Commission Workshop Report, 15-17 Feburary 2000, pp 6171

Grebmeier JM, McRoy CP, Feder HM (1988) Pelagic-benthic coupling on the shelf of the northern Bering and Chukchi Seas. I. Food supply source and benthic biomass. Mar Ecol Prog Ser 48:57-67

Grebmeier JM, Feder HM, McRoy CP (1989) Pelagic-benthic coupling on the shelf of the northern Bering and Chukchi Seas. II. Benthic community structure. Mar Ecol Prog Ser $51: 253-268$

Grebmeier JM, Cooper LW, DeNiro MJ (1990) Oxygen isotopic composition of bottom seawater and tunicate cellulose used as indicators of water masses in the northern Bering and Chukchi Seas. Limnol Oceanogr 5:1182-1195

Hammill MO, Smith TG (1989) Factors affecting the distribution and abundance of ringed seal structures in Barrow Strait, Northwest Territories. Can J Zool 67:2212-2219

Harwood LA, Smith TG (2003) Movements and diving of ringed seals in the Beaufort and Chukchi seas, 1999-2003. In: Abstracts of the 15th Biennial conference on the biology of marine mammals, Greensboro, 14-19 December 2003

Heide-Jorgensen MP, Lydersen C (eds) (1998) Ringed seals in the North Atlantic. NAMMCO Sci. Publ. 1

Innes S, Heide-Jprgensen MP, Laake JL, Laidre KL, Cleator HJ, Richard P, Stewart REA (2002) Surveys of belugas and narwhals in the Canadian High Arctic in 1996. NAMMCO Sci Publ 4:169-190

Johannessen OM, Shalina EV, Miles MW (1999) Satellite evidence for an Arctic sea ice cover in transformation. Science 286:19371939

Kelly BP (1988) Ringed seal Phoca hispida. In: Lentfer JW (ed) Selected marine mammals of Alaska: species accounts with research and management recommendations. US Marine Mammal Commission, Washington, pp 57-75

Kelly BP (1996) Live capture of ringed seals in ice-covered waters. J Wildl Manag 60:678-684

Kelly BP, Quakenbush LT (1990) Spatiotemporal use of lairs by ringed seals (Phoca hispida). Can J Zool 68:2503-2512

Kelly BP, Quakenbush LT, Taras BD (2000) Correction factor for ringed seal surveys in Northern Alaska. Annual Report for 2000 to Coastal Marine Institute, University of Alaska Fairbanks

Kingsley MCS, Stirling I (1991) Haul-out behaviour of ringed and bearded seals in relation to defense against surface predators. Can J Zool 69:1857-1861

Krafft BA, Lydersen C, Kovacs KM, Gjertz I, Haug T (2000) Diving behaviour of lactating bearded seals (Erignathus barbatus) in the Svalbard area. Can J Zool 78:1408-1418

Lowry LF, Frost KJ, Burns JJ (1980) Variability in the diet of ringed seals, Phoca hispida, in Alaska. Can J Fish Aquat Sci 37:2254-2261

Lydersen C, Gjertz I (1986) Studies of the ringed seal (Phoca hispida Schreber 1775) in its breeding habitat in Kongsfjorden, Svalbard. Polar Res 4:57-63

Lydersen C, Ryg M (1991) Evaluating breeding habitat and estimating the size of a local population of ringed seal (Phoca hispida) in Svalbard, Norway. Polar Rec 27:223-228

Lydersen C, Jensen PM, Lydersen E (1990) A survey of the Van Mijen fiord, Svalbard, as habitat for ringed seals, Phoca hispida. Holarct Ecol 13:130-133

McCullagh P, Nelder JA (1989) Generalized Linear Models, 2nd edn. Chapman and Hall, New York

McLaren IA (1958a) The biology of the ringed seal, Phoca hispida, in the eastern Canadian Arctic. Bull Fish Res Board Can No. 118

McLaren IA (1958b) The economics of seals in the eastern Canadian Arctic. Fish Res Board Can Arctic Circular No. 1 
Simpkins MA, Hiruki-Raring LM, Sheffield G, Grebmeier JM, Bengtson JL (2003) Habitat selection by ice-associated pinnipeds near St. Lawrence Island, Alaska, in March 2001. Polar Biol 26:577-586

Smith TG (1973) Population dynamics of the ringed seal in the Canadian eastern Arctic. Fish Res Board Can Bull 181:1-55

Smith TG (1980) Polar bear predation of ringed and bearded seals in the land-fast sea ice habitat. Can J Zool 58:2201-2209

Smith TG (1981) Notes on the bearded seal, Erignathus barbatus, in the Canadian Arctic. Can Tech Rep Fish Aquat Sci 1042

Smith TG (1987) The ringed seal, Phoca hispida, of the Canadian western Arctic. Can Bull Fish Aquat Sci 216:1-81

Smith TG, Hammill MO (1981) Ecology of the ringed seal, Phoca hispida, in its fast ice breeding habitat. Can J Zool 59:966-981

Smith TG, Lydersen C (1991) Availability of suitable land-fast ice and predation as factors limiting ringed seal populations, Phoca hispida, in Svalbard. Polar Res 10:585-594

Smith TG, Stirling I (1975) The breeding habitat of the ringed seal (Phoca hispida). The birth lair and associated structures. Can J Zool 53:1297-1305

Smith TG, Stirling I (1978) Variation in the density of ringed seal (Phoca hispida) birth lairs in the Amundsen Gulf, Northwest Territories. Can J Zool 56:1066-1070
Smith TG, Hammill MO, Taugbol G (1991) A review of the developmental, behavioural and physiological adaptations of the ringed seal, Phoca hispida, in its fast-ice breeding habitat. Can J Zool 59:966-981

Stirling I, McEwan EH (1975) The caloric value of whole ringed seals (Phoca hispida) in relation to polar bear (Ursus maritimus) ecology and hunting behavior. Can J Zool 53:1021-1027

Stirling I, Kingsley M, Calvert W (1982) The distribution and abundance of seals in the eastern Beaufort Sea, 1974-1979. Can Wild Serv Occas Paper 47

Stoker SW (1981) Benthic invertebrate macrofauna of the eastern Bering/Chukchi continental shelf. In: Hood DW, Calder JW (eds) The eastern Bering Sea shelf: oceanography and resources, Vol. 2. Univ Wash Press: Seattle, pp 1069-1090

Venables WN, Ripley BD (2002) Modern applied statistics in S, 4th edn. Springer, Berlin Heidelberg New York, pp 1-512

Vinnikov KY, Robock A, Stouffer RJ, Walsh JE, Parkinson CL, Cavalieri DJ, Mitchell JFB, Garrett D, Zakharov VF (1999) Global warming and Northern Hemisphere sea ice extent. Science 286:1934-1937

Wyllie-Echeverria T, Wooster WS (1998) Year-to-year variations in Bering Sea ice cover and some consequences for fish distributions. Fish Oceanogr 7:159-170 